\title{
The Sexist Beliefs That Underlie in the Pedagogy about Obesity in Physical Education Classes
}

\author{
Núñez-Rivas Hilda Patricia1, Holst-Schumacher Ileana ${ }^{2 *}\left(\mathbb{0}\right.$, Campos-Saborío Natalia $^{3}$, \\ Alfaro-Mora Flory Virginia ${ }^{4}$ \\ ${ }^{1}$ Costa Rican Institute for Research and Education on Nutrition and Health, Tres Ríos, Costa Rica \\ ${ }^{2}$ Universityof Costa Rica, San Pedro Montes de Oca, Costa Rica \\ ${ }^{3}$ State University at Distance, Sabanilla, Costa Rica \\ ${ }^{4}$ Costa Rican Institute for Research and Education on Nutrition and Health, Tres Ríos, Costa Rica \\ Email: hnunez@inciensa.sa.cr, *ileana.holst@ucr.ac.cr, nataliacampos07@yahoo.com,valfamo@inciensa.sa.cr
}

How to cite this paper: Patricia, N.-R. H., Ileana, H.-S., Natalia, C.-S., \& Virginia, A.-M. F. (2019). The Sexist Beliefs That Underlie in the Pedagogy about Obesity in Physical Education Classes. Advances in Physical Education, 9, 197-214.

https://doi.org/10.4236/ape.2019.93014

Received: June 19, 2019

Accepted: August 10, 2019

Published: August 13, 2019

Copyright ( 2019 by author(s) and Scientific Research Publishing Inc. This work is licensed under the Creative Commons Attribution International License (CC BY 4.0).

http://creativecommons.org/licenses/by/4.0/

\section{Open Access}

\begin{abstract}
The physical education class and the teacher's guide to this subject are key elements to make physical activity a habit for life. This article describes the sexist beliefs that underlie in the pedagogy about obesity in physical education classes. The ethnographic method was used in a public urban school of San José, Costa Rica. A sample of 210 students and five physical education teachers participated. The results indicate that sexist beliefs of teachers affect the pedagogical treatment of obesity. Among these effects are the exclusion and inattention of students with obesity in the practice of this subject and the privilege that teachers give to students with normal nutritional status. The data show that girls and boys with obesity or those who lack traits related to masculinity fail in physical activity and are excluded. It is necessary to re-signify the practice of the teacher of physical education to achieve an inclusive education.
\end{abstract}

\section{Keywords}

Obesity, Sexism, Physical Education, Beliefs, Pedagogy

\section{Introduction}

The physical education (PE) class and the teacher's guide of this subject have great importance in health promotion, since sedentary lifestyle is a risk factor for the development of obesity and the comorbidities associated with it (Cantera \& Devís, 2002). Some of the girls, boys and adolescents do not comply with the 
recommendations regarding physical activity. However, the participation of students will not only depend on biological factors, but also, in the teacher's training, the curricular focus of this subject, which gives or not place to motor elitism and in turn to the psychosocial influence respect to sexist beliefs and stereotypes (Beltrán, Devís, \& Peiró, 2012).

PE curriculum triggers biological and hygienic improvements (physical condition and health), perceptive (organization and body structure), cognitive (problem resolution) and social related with motor behavior in society (body expression, cooperation). The authors believe that the integral perspective of $\mathrm{PE}$ programs must include themes such as obesity, bulimia, anorexia, ethnic identity and sport values. $\mathrm{PE}$ also offers benefits in the performance of movements, in the affective-emotional (motivation to the ego and tasks) and spiritual improvements (moral and ethical) (Gil \& Contreras, 2005).

Likewise, it should be considered that, in the integration process of girls and boys into society, the family, the peer group, the media, the work of the educational center as a socializing institution, among other instances, they all influence and provide models to imitate. Therefore, the process of forming sexual roles has been explained in three ways: direct instruction, direct reinforcement and modeling. According to Garret and Kehr (1985) the most important aspect is the one based on the observation of other people (modeling or imitation), which includes three sequential basic processes: observation, abstraction and action.

In this sense, girls and boys observe the behavior differences in their environment, learning through the reinforcement of the models accepted and expected according to sex. Subsequently, the experiences are generalized to apply them in their own behavior. According to Perry and Bussey (1979) in this last phase, girls and boys tend to present stereotyped behaviors, as they expect reinforcements from their behavior and foresee punishments otherwise.

Other pioneer researches in this field, evidence that most people identify their sex between two and three years of age (Thompson, 1975) and around the seven years they realize that sex does not change, it is a permanent attribute (Slaby \& Frey, 1985; McConaghy, 1979). According to Eaton and Von Bargen (1981) the knowledge of the sexual role is learned first about its own, then about people of the same sex and finally the "opposite sex". The identification of sex roles and stereotypes begins at an early age, which will continue to be completed in its most basic aspects until the end of primary education (Emmerich \& Sheperd, 1982). The family is especially important in the first stage for the presentation of models in the home, which are reinforced or questioned with the entry to school.

This is how; the mentioned explanations have been recently validated. In 2014, theories related to sex roles were discussed, considering the interactions between couples of different sexes and how girls and boys relate each other in school. It was reported that girls and boys tend to separate into groups of same-sex and that gender segregation is later due to the influence of their part- 
ners. In the case of the public school in Costa Rica, which is financed by the State, it has a special responsibility regarding these interactions and must provide an education for at least six years, which allows the development of potentialities without racial, religious, political or sexual discrimination. One of the aspects that differentiates the educational center from the other social organizations is that it constitutes a mandatory legal stimulus for at least eleven years.

In addition to the foregoing, it is important to point out that in much of the international scientific literature on the issue of obesity linked to "machismo" and PE, emphasis has been placed on practices, attitudes, perceptions and images (Piedra, Anderson, Colás-Bravo, Fernández-García, Gard, et al., 2013; Arroca y Llano, 2008, Moreno, 2011, Saraví, 1995, Piedra, García, Latorre, \& Quiñones, 2013). However, beliefs have not been addressed, so this article contributes to scientific knowledge.

The present investigation focused on revealing the beliefs of the teachers and the sexism that underlie the pedagogical treatment of obesity in the PE classes. Of great interest was the profound understanding of how the beliefs of PE teachers about the obesity of girls and boys of school age, within the framework of dominant hegemonic masculinity, favor or hinder the prevention of this condition and affect the biological and psychological development of these students. Therefore, the study analyzed aspects related to discrimination by sex or sexism in the PE subject, as a reference to those forms of social activity that discourage the development or people's actions because of their sex.

\section{Theoretical Framework}

The beliefs according to Quintana (2001) are: "a set of meta-empirical realities and ideas that people or groups accept, recognize, as a principle of how much they want to think, do and wait, in the ultimate orientation of their lives". All these factors of cognitive and affective beliefs illustrate that girls and boys are actively involved in the construction of the social world that surrounds them where the sex roles are an important part (Martin, Fabes, \& Hanish, 2014), not only from the biological point of view. In the same way, teachers can express implicit and explicit sexist attitudes and show differential treatment for boys or girls. Children's peers take these sexist actions explicitly encouraged by teachers (Leaper \& Brown, 2014).

Teachers' beliefs are implicit perceptions about learning and teaching, deeply rooted, not only in the dominant school culture, but also in everyday teaching activities such as planning, classroom organization, educational practice and evaluation, among others (Durán, 2001). A study with students from 8 to 11 years of age from five schools in Cuenca (Spain) explored the perceptions of boys and girls to perform physical activity during recess, from their own perspective. The results showed that, despite the fact that the boys and girls identified the same barriers, there were gender differences in their perceptions. For example, children preferred to play football and the sport had a monopoly on recreational space. Those girls and boys, who did not play football were dis- 
placed to peripheral areas and the lack of materials was a barrier for them. Likewise, the teachers themselves were a barrier for all children who did not play football (Martínez, Gutiérrez, Rodríguez, Pardo, \& Martínez, 2017).

In the teaching practice, asymmetric relations of power are given between students who show "more masculine" characteristics than others. Therefore, this study analyzes the educational practices of PE teachers, from the following critical perspectives: sexism (refers to all those practices and attitudes that promote differentiated treatment of people by reason of their biological sex, which assumes that women and men act daily with expected characteristics and behaviors), masculinity (set of attributes such as strength, violence, aggression associated with the traditional role of the male category and is related to the idea that it is necessary to be continually testing and proving that one is a man); "machismo" (it is a form of hypermasculinity whose characteristics are subject to the context, historical moment and culture) and feminism (set of attributes associated with the traditional role of the female category). These asymmetries and exclusions must be understood within the framework of dominant hegemonic masculinity (se constituyeen el parámetro de lo que en la sociedadpatriarcalsignificallegar a ser un "verdadero hombre"), typical of the western society (Connell, 2005; Goetz \& Le Compte, 1998).

By tradition, the planning of the PE class has been based on principles of medical and biological sciences and has not yet been considered the social and cultural part of the human being (Fernández, 2011). The simplistic, biologistic and competitive perspective of PE is reflected in the speech of the teaching staff, that means, in the language used in their practice, where their excluding sexist beliefs are ingrained.

\section{Methodology}

\subsection{Research Design}

This qualitative research was realized with an ethnographic approach, a case study modality (Goetz \& Le Compte, 1988). A public urban school in the province of San José in Costa Rica was analyzed. The field study was conducted, from Monday to Friday for a minimum period of four hours per day for approximately 10 months. Therefore, a specific social phenomenon was studied, a case in depth (Rodríguez, Gil y García, 1996, Schensul, Schensul, \& Le Compte, 1999). The population selected for the study consisted of students from three groups of third and fourth grade of general basic education. Girls and boys were classified according to their nutritional status, according to the criteria issued by the World Health Organization and the American Pediatric Association (WHO, 1995). Those students classified with obesity constituted the analysis units of the study together with 5 teachers (two women and 3 men) of PE, who have universitary studies in Sports Science or PE and extensive work experience. Girls and boys of first grade of general basic education were excluded from this study since they were considered inadequate informants because they 
were beginning to read and write.

\subsection{Data Collection}

Data was collected using a wide variety of techniques in order to capture reality in its entirety: participant observation, depth interviews, focus groups, an instrument with incomplete sentences and documentanalysis (Woods, 1987, Flick, 2004, Schensul, Schensul, \& Le Compte, 1999). A total of 16 focus groups with 6 to 8 students (regardless of nutritional status) in each group participated; four groups only of girls and four groups only of boys. Subsequently, eight more focus groups were conducted, in a mixed manner (boys and girls). This with the aim of ensuring homogeneity and prevent stigmatizing the student population with obesity condition. According to the qualitative literature, the focus groups were designed to be as homogeneous as possible in demographic terms of the participants in order to facilitate the debate (Traynor, 2015) and to address the objectives and hypothesis of the research.

The discussions with each of the groups lasted approximately 70 minutes. The focus groups were held in classrooms assigned by the principal of the school, with seats arranged in a circular formation to encourage open discussion. Focus groups were moderated and transcribed alternately by the four authors. Each discussion was recorded with two journalistic recorders and two of the authors alternately took note of the speeches, while the other two researchers, also alternately, moderated the discussions. The recordings were transcribed (maximum one week after) by the researchers (one fourth of the total of the focus groups for each one) and the transcriptions were supplemented with the notes that the authors took during the discussions, in order to avoid the memory bias and to guarantee coherence and convergence of the speeches and their interpretations.

The instrument with incomplete sentences was applied to the students with obesity in order to investigate their ideas and feelings about obesity. All these techniques allowed us to collect abundant and rich meaning data that, when triangulated by sources, validated the results of the research, as pointed out by Maxwell (2002) and Le Compte and Schensul (1999).

Testimonies from the PE teachers that underlined concepts of sexism, masculinity, "machismo" and feminism were selected and the speech analysis method (Pochet, 2000, Santander, 2011) was used with the intention of determine their domains and borders while confronting them with theoretical foundation. Consequently, the practice of the PE teachers can be re-signify, looking forward the achievement of an inclusive and fair education that takes diversity into account.

\subsection{Data Analysis}

The computer program ATLAS. ti (version 7) was used to analyze the qualitative data and 126 documents were assigned, including interviews and observation chronicles. Literal transcriptions were used for depth interviews and focus groups and thematic analysis was used to analyze the data. All transcripts were 
coded as a team by the four authors, using the software mentioned. This resource facilitated the organization and classification of this information in order to extract the most relevant meanings about obesity in students and teachers of the school. In addition, audio recorders were used to record PE classes and interviews and digital camera to document the activities and behaviors of the people observed.

Ethical considerations: This study was approved by the scientific committee of INCIENSA. All adults and children over 12 years of age were consented and assented respectively to participate in the study and respect the students' willingness to collaborate. Girls and boys under 12 years of age had the consent of their parents.

\section{Results}

The results of the analysis of those testimonies of the speech of the teaching staff of the PE that have sexist contents and valuations related with obesity are exposed in the next paragraphs:

\subsection{Obesity: A Condition That Makes the Participation of Girls and Boys Invisible in PE}

In the following testimony of a teacher an excluding speech is evidenced not only from the motor aspect (obesity affects physical performance) but also the "machismo" is evident:

"Roberto (refers to a child of third grade with obesity) who is another boy that you observe (refers to the researchers) is a slowness for everything, he gasps when he runs, please forgive the expression ... and in general he do not last active for long. I can't tell you if it s laziness or what, because they do not like physical activity. I tell you that the girls and that little boy named Juan, are prejudiced that they will not achieve it before doing something".

On the other hand, the teacher adds:

"(...) Irene is another girl, she is chubby, no, no, do not choose her jaah! And why they don't choose her? Because this little girl is not good for competition and they like to compete, win, they are very competitive, right?"

\subsection{Masculine Active Girls and Obese Boys with Feminine Characteristics}

In this category, the following testimonies are presented:

"I would say there are more girls with overweight than with obesity, but, for example, Margarita (refers to an obese girl of fourth grade) who is a girl who is ... you see her and she is packed, she is hard and she is active. I tell you this girl, I do not know how you have classified her (refers to the researchers), overweight or obese, but if that little girl was overweight ... that girl is not, because she is not sedentary. I understand, is not that I say that she is not chubby, I do not say that, but if she has overweight, it must be because she eats a lot. And you have seen her in the classes, this little girl plays soccer, the boys choose her." 
“9:30 a.m. (...) See right now how are they (refers to two obese girls of fourth grade) sweating and do not mind getting dirty. They play with the boys, if they have to fall to the ground, they throw themselves and continue (...). I think Margarita plays more than Betty because Margarita is always active and Betty is more effeminate, but Margarita is not, she is more natural, spontaneous, maybe, I do not know (...) I $m$ telling you, the other girls not, no, they are not active at all (...)".

In the following testimony the relegation of masculinity appears when a boy is labeled with feminine adjectives:

The boy named Gerardo, who is in a soccer school and therefore the teacher gives him a privileged place as a leader in the group, says that not everyone could play everything. "someone who does not have enough air to run, ehh, it may be that the 'Beautiful Fat Girl (laughs)." (He refers to an obese boy with the nickname "Beautiful Fat Girp").

Likewise, another boy of the group validates this "subordinate variant" of hegemonic masculinity posed by Vidiella, Herraiz, Hernández, \& Sancho (2010), when expressing:

"Yes, you see, is better that 'Beautiful Fat Girl becomes the goalkeeper because he does not run very much and today he did not want to play, then as Manolo also knows how to catch good and everything, then Manolo played goalkeeper today. In this regard, the teacher added that 'another little boy, who is not any more in this school, said'Beautiful Fat Girl that he had to be a goalkeeper because he covered aaaall111111111 the goall1111111".

In this regard, the obese child with the nickname "Beautiful Fat Girl" (making allusion to the title of a Venezuelan soap opera) responds: "I am the official goalkeeper (laughs), because I am good catching and I, sometimes, can run fast the whole game, but sometimes not because I get tired and because one day I bent my ankle (...)".

\subsection{Teachers Who Promote a Dichotomous Educational Practice with Their Masculinity Glasses}

\subsubsection{Exclusive Pedagogical Practice towards Girls with Obesity}

The teacher instructs her students to make groups of five and an obese girl (named Sonia) is left without a group. Then, she goes to the teacher to tell her that she was left out of the groups. The teacher replies: "Go and look for those who need to fill the group and get there." A classmate of Sonia tells the teacher: "Teacher, Sonia is not doing anything, she has stopped doing the exercises". The teacher answers: "Well, well, it's okay, leave her alone, it doesn't matter, leave her". Then she goes to the researcher and says: "Sonia is like a lost case, I do not demand her much". The way this teacher understands masculinity precedes an excluded pedagogical practice with obese boys and girls. A similar situation has been reported regarding the girls' learning in mathematics; the expectations of parents and teachers are biased by gender and they negatively influence their at- 
titudes and performance in comparison with their male peers (Gunderson, Ramírez, Levine, \& Beilock, 2012).

\subsubsection{Privileged Pedagogical Practice towards the Student Population with Normal Nutritional Status}

During the research, a pattern was also observed in one of the PE teachers when performing the warm-up exercises. She always selected a student with normal nutritional status to lead the class in front of her classmates. These discriminatory behaviors were reproduced by their students, when they led the group. These learned patterns, through processes of social reproduction, were reflected in the social interactions of their students.

\subsection{The Body Is a Sign, It's a "Message" That Speaks of Its Owner}

Regarding this category, a PE teacher pointed out that:

"The girls are ... well, there are some fat or thin girls who do not like to get dirty or sweat or even mess up. They like playing soup operas ... they are always doing other things. No, sometimes with women is very hard, sometimes I surrender. They want to be thin, but they do not collaborate and the girls that have curly hair want to have straight hair and the very white ones want to be tanned, but you will see them sitting in the shade."

Summary of results: The main results of this study reveal that the obesity is a condition that makes the participation of girls and boys invisible in PE classes. The beliefs about obesity are crystallized in the pedagogical practice, causing the student population in relation to physical activity, to be categorized into two types of students: masculine active girls and obese boys with feminine characteristics. These macro-categories, which were revealed by the beliefs of physical education teachers, make it possible to promote a dichotomous and non-inclusive educational practice since PE teachers privilege only those students with a normal nutritional status. Also, through processes of social reproduction, the PE teachers reinforce the belief in the students that the body is a sign that is used to select those who are good for physical activity from those that are not so good. In other words: the body is a "message" that speaks of its owner.

\section{Discussion}

The PE teacher's training, the awareness of the role he/she plays in promoting an equal environment, as well as the hidden curriculum and the paradigm he/she uses during the classes, gives rise to equality and motivation or otherwise motor elitism that triggers exclusion by physical condition or by the absence of motor skills. This type of elitism is encouraged when the teacher makes use of the paradigm centered on physical fitness which seeks to improve physical performance and promotes competitiveness among students (Devís \& Pereiró, 1993).

Motor elitism is not only related to the presence of skills and physical competencies, but in turn is influenced by sexist stereotypes, social beliefs of 
peers and teachers (Devís \& Pereiró, 1993). For example, the condition of obesity in the child called "Beautiful Fat Girl", cancels his masculinity condition, because this child does not demonstrate the characteristics of masculinity that the patriarchal society demands of him as a man: strong, competitive, successful, fast, flexible and resistant.

Likewise, the PE teacher's belief about obesity, does not make visible girls and boys with this condition, so that obesity favors motor elitism. This condition prevents both men and women from carrying out the arbitrary role that the patriarchal society has imposed on them. The testimonies showed a speech that points to the conception of a $\mathrm{PE}$ that is more competitive than participative and that leads to reinforce the stereotype that the students with obesity are unsuccessful. The performance of girls and boys with obesity in physical activity is addressed by different studies (Moreno, 2011, Rosales, Vicente, \& Fleitas, 2005, Toro, 2007, Vázquez, 2001a) and is limited to teachers who believe that the purpose of the PE is to promote the physical condition of girls and boys and the practice of sport, mainly football, leaving aside other recreational and sports activities in which girls and boys would have more opportunities to integrate and make physical activity a habit for life.

The belief that slowness is inherent to obesity, either because people with obesity are slow or because "(...) in general do not last long active (...)" or "because (...) they think that they are not going to achieve it (...)", causes the girl or boy with obesity not to be chosen by their peers to make team, because in the words of a PE teacher: "(...) they are not good for competition".

Therefore, the findings of this study suggest that the obesity condition equals girls and boys and reduces sexism, since the culture of success plays an important role, an aspect that neither the school nor the beliefs of the teacher of PE are released, because it covers and permeates the daily school and pedagogical work.

Likewise, it can be observed, in the testimonies that precede, that the teacher pointed out that obese students are people disqualified for physical activity. The teacher explains her beliefs, in relation to the behavior of the female gender, but in the teaching practice, she was not requesting students attention toward the behaviors labeled for girls. Neither, she offered alternatives to include students in the games, which was opposed to the educational purpose: "To foster in the students an integral conception of reality, by using recreational activities as a means for a meaningful and permanent learning" (Ministerio de Educación Pública, 2005). In these testimonies the beliefs of the teaching staff about the focus of the aforementioned subject and their beliefs about PE and gender were revealed.

In beliefs, the thinking, feeling and acting of people towards masculinity, sexism, "machismo" and feminism are expressed. The sexist attitudes of masculinity and "machismo", are based on traditional beliefs and stereotypes about the different gender roles and this phenomenon do not exclude teachers. Beliefs are part of the cognitive structure of teachers and students (Pozo, 2000) (Vázquez, 
2001b). They are inserted in the ideas, perceptions and attitudes of teachers, consciously or unconsciously, and guide their decisions when planning and putting into practice their academic offer.

It is essential that the PE teacher promotes teaching from a paradigm oriented to physical activity and to enjoy it in conditions of equality. The teacher must rationalize that physical activity itself and its impact on health is much more important than performance and physical condition. Likewise, he/she must guide the classes from a holistic perspective, which allows the critical reflection of social beliefs and stereotypes and, finally, should encourage solidarity, tolerance and the desire for personal improvement (Devís \& Pereiró, 1993).

Girls and boys have the right to enjoy of the PE classes and, therefore, it is the teacher's duty to eradicate motor elitism, which discriminates and defines the possibilities of being chosen based on sexist patterns and motor skills, since this results in the abandonment of sports practice, affects the self-esteem and performance of many children (Piedra, 2015).

Therefore, in the professional training of the physical educator, the ability thinking about equality towards freedom of movement and expression must be developed, in order to generate spaces for coexistence and not discrimination. In addition, teachers must be sensitized in the identification and management of sexist stereotypes, otherwise the dominant version of masculinity will be consolidated and competitiveness and the value of the physical will be promoted (Piedra, 2015).

It is worth mentioning that, repeatedly, the speeches of the PE teachers show that their pedagogical practice is impregnated with "machismo" that promotes an insane competition, based on biological traits, pointing out that girls must assume the social role assigned to the boys in the sports: they must have physical strength, competitiveness and resistance (Cremades, Álvarez, Urruzola, Jaramillo, \& Hernández, 1995). The girls who show physical strength, competitiveness and resistance are accepted and considered appropriate for sports by the boys; although their overweight or obese conditions. Vázquez points out that the participation of women in sports has been constrained by myths such as: "sport gives male traits to women ... and also, it is dangerous for women's health ... women do not have the skills or interest in sports" (Vázquez, 2001a: p. 59).

So the cultural construct of competitiveness and success is linked to masculine qualities. “...boys are more violent, aggressive, creative, restless ...” (Subirats, 1988: p. 206) and women who have these qualities, with or without overweight or obesity, are accepted, because they fulfill the perspective of hegemonic masculinity (Carrigan, Connell and Lee, cited by Espada-Calpe, 2004). On the contrary, those girls who show characteristics of femininity are considered unsuitable for sports and competitiveness. Also, a derogatory attitude was perceived in this teacher towards what she believes is "feminine", being a more passive condition and therefore not suitable for sports. Historically, women have participated in sports such as tennis, gymnastics and swimming, activities that fit into the 
traditional female model (Pelegrín, León, Ortega, \& Garcés, 2012).

It is evident that sport is reserved for men and that the participation of women is bad seen by prejudices, beliefs and traditional ideologies about femininity that constitute a barrier to the promotion of physical activity, its delight and attitude towards it, because there is no recognition and equal treatment (Puig \& Soler, 2004).

Historically, patterns have been established for each gender that gives rise to asymmetric practices, where man must develop strength, quickness, competition, while woman its charms and flexibility, otherwise occurs a virilization of her function as a woman, as well as her role of mother is threatened. Man is expected to finish the PE class unkempt and the woman almost without sweating (Scharagrodsky, 2004).

The deficiencies towards the girls indicated by the teachers and the distance with "the expected", are constructed from the behavior of the students, not from their competences, potentialities, attitudes and aptitudes. The traits of femininity are the explanations that justify poor performance in PE. School, in the words of Bourdieu "exercises one of the most powerful social magistracies of our society that has the power to condemn (you are anidiot or null) or to consecrate symbolically (you are intelligent)" (Bourdieu, 1997).

Blández, Fernández and Sierra (2011) found a clear differentiation towards one type or another of physical-sport activity in schoolchildren in different ways. Boys considered that "aggressive" sports are not liked by girls, because of the perception that it takes great physical demand for girls, opposed to the given esthetic and recreational perception assigned to them by society.

Other research reported that both girls and boys showed significantly more favoritism for traits of their own sex than for traits belonging to the other sex (Robnett \& Susskind, 2010). Likewise, the results of that investigation indicated that same-sex friendships of those boys who reported having many friends, lacked stereotyped feminine traits.

These results, as well as those of our study, provide work hypotheses to study and deepen the norms of masculinity within the peer groups that predominate in boys. They also suggest that peer groups dominated by male-children can play a role in the socialization of negative attitudes about femininity that some men show later in life (Robnett \& Susskind, 2010).

On the other hand, being overweight, obese or having some type of disability are conditions to place some boy or girl in a subordinate position (Vidiella, Herraiz, Hernández, \& Sancho, 2010). From the above, the results of our study show that students with obesity have decoded the implicit messages, issued by their partners and the PE teachers, as follows: "they know (some obese children) that they have to play goalkeepers", "because they are slow", "they do not last a lot being active", "they think they are not going to achieve it 'and' they are not good for competition". This decoding denies the aims of the PE, in terms of strengthening the skills of the students with physical exercises, sports and crea- 
tivity, for the achievement of a healthy life and a peaceful and solidary coexistence among human beings with obesity or without her.

Therefore, it is necessary to learn to reflect critically on the action. Only in this way will the interpretations and judgments of the teaching staff and students will become more coherent and less dependent on the prejudices and dogmatisms of which the unthinking mentality is saturated (Carr \& Kemmis, 1988). This thoughtless attitude has focused the teacher's concern on his performance, but it has not been able to contextualize teaching, nor focus the real learning of the students. Therefore, they link "no learning" with diverse causes (students without skill, not flexible, carefree parents, no resources, among others) but not with teaching and, therefore, cannot re-think their actions to improve them. When analyzing these teaching practices, this study unveils two unfortunate losses related to a fundamental principle of the teaching profession, which is to focus on the subject that learns. The losses referred to are: loss of the subject and loss of understanding (Pruzzo, 2005, Pruzzo \& Nosei, 2008).

The subject is lost when the didactic strategies lose sight of the student as the subject of learning, neglecting their needs or demands. This loss of the subject is accompanied by an assembly of exculpation, since the teachers are teaching or fulfilling their obligation, so that learning is not linked to their own practice (Pruzzo, 2005, Pruzzo \& Nosei, 2008).

The loss of understanding (Pruzzo, 2005, Pruzzo \& Nosei, 2008) refers to the teaching action that disregards teaching for understanding, the teacher has lost the purpose of their task. While the loss of the subject focuses on the loss of the active role of the subject who learns from their experiential culture and motivations, the loss of understanding is the dislocation between critical culture (scientific knowledge) and academic culture (school content) and especially, with an institutional culture that favors academicism and positivism and a competitive and "macho" conception of the PE, instead of a participatory or inclusive one, where overweight and obese students have the chance of success.

It is important that the teacher re-thinks his professional culture and if this gives rise to a hegemonic culture through a hidden curriculum. Subirats, 1988: p. 214, states that "sexism must be eliminated and a coeducational school must be built ... to redo the system of values and attitudes that are transmitted and to re-think the educational contents". Likewise, one should avoid perceiving the body as a machine to combat the motor elitism that only generates exclusion and devalues those who go beyond the ideal physical-sporting pattern. On the other hand, it must be formed to combat sexist stereotypes that assign a passive role to women, because their ability to conceive is mistakenly protected, while man is treated as a machine whose value is measured in relation to his physical abilities (Barbero, 1996).

As observed in the findings of our study, happiness and personal fulfillment are increasingly subject to the degree to which our bodies fit contemporary standards of health and beauty, so the body is a sign, it is a "message" that talks 
about its owner. In the consumer society the body becomes a commodity, which becomes its main object of production and distribution.

The "culture of consumption" is present in the current school and it seems that it has no choice but to adapt to the "new citizen-consumer", as was found in the school of this research. For example, in the multiple moments in which the teachers "selected" the girls and boys "with model bodies" to perform some physical exercise, in front of their peers; those "peers" were always made up of children, whose bodies are "slow, do not last long active, they think they will not achieve it and they are not good for competition" and, in addition, they provoke "social disturbances" (Portela, 2001).

According to Santos Guerra, M. A. (1991) cited by Vázquez (2001a), the PE must have objectives in accordance with the development of the corporal values, such as: knowing the body, developing the body, feeling the body, caring for the body, accepting the body and integrating the corporal values within a scale of values. Likewise, Barbero (2005) affirms that the PE classes have the possibility of being an agent of body culture that can intervene in two aspects through their messages and teachings: it reproduces the values of the hegemonic body culture, associated with the culture of success and the exaltation of the body or on the contrary motivates to develop knowledge to confront and resist the new prevailing tendencies of postmodern society.

In this socio-cultural framework, "machista" and "consumist", the development of the PE classes constitutes lost educational opportunities and moves away from the vision that the knowledge and skills or competences that students acquire in this subject, will benefit them throughout their lives and will allow them to thrive in a world in constant change, helping them to develop the understanding, the capacity and the commitment to lead a healthy and active life (Ministry of Education, 2015).

\section{Conclusion}

The beliefs of PE teachers about obesity, manifest a "macho" vision in their educational practice: they do not take into account overweight or obese students; on the other hand, they privilege those with normal nutritional status. In fact, the teachers dichotomize their pedagogical practice because they divide the capacities of girls and boys, based on an arbitrary "macho" label. Thus, they legitimate the conception of hegemonic masculinity by allowing their students to assign female qualities to obese boys ("Beautiful Fat Girl"). In the same way, the teachers attribute masculine qualities to girls who are more competitive, active and less careful with their physical appearance.

It was observed in several testimonies how the beliefs of the teacher about physical activity and gender are reproduced by the students; calling "Beautiful Fat Girl" a boy who is slow and he is not competitive, because of his obesity. This is a trait that the research results give to the female gender (Cremades, Álvarez, Urruzola, Jaramillo, \& Hernández, 1995). It seems that a male with 
these characteristics is associated with the behavior of girls.

They also underestimate the femininity of girls who do not show a more active, dynamic and competitive behavior in sports because they do not consider it successful. The absence of the constructs of masculinity, sexism, "machismo" and femininity in the teachers of PE, makes that sexist behaviors and attitudes do not transcend educational practices. This study largely justifies that, in Costa Rica, educational guides should be prepared for a non-sexist PE, such as the one coordinated in Spain by Benilde Vázquez and Gonzalo Álvarez (Álvarez, Cano, Fernández, Lopez, Manzano, \& Vázquez, 1996) and considering that "coeducation is not about getting girls to do or have to do, by force, everything that boys do" (Asins, 1999). Also, this research evidences the need to carry out more qualitative studies that deepen into the masculinity norms of peer groups dominated by male-children because they could play an important role in the socialization of negative attitudes about femininity.

Finally, the authors recommend the teaching staff to put into practice, as soon as possible, the proposals for change that have been proposed, in order to break this obsolete and reproductive sexist and discriminatory culture and open the way for new and more supportive, respectful, tolerant, humanistic generations with greater confidence in their physical abilities, talents and desires to be healthy and free, through a systematic and habitual practice of physical activity. Therefore, to promote physical activity in all areas of the school, PE classes and extracurricular scenarios (recreation and daily activities), those responsible for public health and educational policies must take into account gender socialization and promote inclusive physical activity in schools.

This study broadens the understanding of how obesity and physical activity interrelate in accordance with the "macho" beliefs of PE teachers. Diverse ideas are induced by teachers that stereotype the differentiation of the sexes, since roles have been designated, underestimating gender and giving unequal treatment to students in PE classes, with respect to masculinity and femininity.

Therefore, efforts should be channeled to:

- Include the theme of non-sexist education in the curriculum of the universitary career of PE and in study programs of schools and high schools in this subject, with a body concept not only biological but also expressive, artistic and spiritual, carried out with a holistic, participative and inclusive methodology.

- Train the PE teachers and professors with the holistic approach in mind, in order to educate children with the conviction to eradicates exist values from their beliefs. Therefore, they can create an environment of healthy coexistence, where girls and boys, develop their personality according to their talents without being subordinate to the hegemonic male or female models.

- Supervise the teaching practice of $\mathrm{PE}$, in order to eradicate the sexist language used, by the teachers, which is reflected in their attitudes and behaviors of exclusion towards students by sex and nutritional status.

- Promote in managers/administrators of educational centers substantial changes to minimize barriers, such as inadequate and insufficient infrastruc- 
ture and materials, training in diverse non-traditional sports, budget for acquisition of necessary material to instrumentalize/operationalize study programs.

\section{Funding}

No funding was received for this study.

\section{Ethical Approval}

All procedures performed were in accordance with the ethical standards involving human participants of the institutional research committee and with the 1964 Helsinki declaration and its later amendments or comparable ethical standards.

\section{Informed Consent}

Informed consent was obtained from all individual participants included in the study.

\section{Conflicts of Interest}

The authors declare that they have no conflict of interest.

\section{References}

Álvarez, G., Cano, S., Fernández, E., López, C., Manzano, A., \& Vásquez, B. (1996). Guía para una Educación Física no Sexista (pp. 5-143). Madrid: Ministerio de Educación y Ciencia, Centro de Publicaciones, Secretaría General Técnica.

Arroca Cifuentes, F., \& Llano Ortiz, J. (2008). Actitudes de género en alumnas/os de E.S.O. Albacete.

http://www.albacete.es/es/por-temas/igualdad-y-participacion/ficheros/actitudesdegen eroenalumnos-asdee.s.o-versinultima2.pdf

Asins, C. (1999). Educar, ¿contra qué? Apunts, 56, 107-109.

http://www.raco.cat/index.php/ApuntsEFD/article/viewFile/307030/397009

Barbero, J. (1996). Cultura profesional y curriculum en educación física. Reflexiones sobre las (im)posibilidades del cambio. Revista De Educación, 311, 13-49.

http://www.mecd.gob.es/dctm/revista-deeducacion/articulosre311/re3110200458.pdf?d ocumentId=0901e $72 \mathrm{~b} 81272 \mathrm{f} 74$

Barbero, J. I. (2005). La escolarización del cuerpo: Reflexiones en torno a la levedad de los valores del capital "cuerpo" en Educación Física. Revista Iberoamericana de Educación, 39, 25-51. http://www.rieoei.org/rie39a01.pdf

Beltrán-Carrillo, V., Devís-Devís, J., \& Pieró-Velert, C. (2012). Actividad física y sedentarismo en adolescentes de la comunidad valenciana. Revista Internacional de Medicina y Ciencias de la Actividad Física y el Deporte, 12, 123-137.

http://cdeporte.rediris.es/revista/revista45/artactividad266.htm

Blández, J., Fernández, E., \& Sierra, M. (2011). Estereotipos de género, actividad física y escuela: La perspectiva del alumnado. http://Hdl.handle.net

http://hdl.handle.net/10481/17510

Bourdieu, P. (1997). Razones prácticas: Sobre la teoría de la acción. Madrid: Anagrama. 
Cantera-Garde, M. Á., \& Devís-Devís, J. (2002). La promoción de la actividad física relacionada con la salud en el ámbito escolar. Implicaciones y propuestas a partir de un estudio realizado entre adolescentes. Apunts, 67, 54-62.

http://www.raco.cat/index.php/ApuntsEFD/article/viewFile/306261/396165

Carr, W., \& Kemmis, S. (1988). Teoríacrítica de la enseñanza. Barcelona, España: Martínez Roca.

Connell, R. (2005). Growing up Masculine: Rethinking the Significance of Adolescence in the Making of Masculinities. IrishJournalofSociology, 14, 11-28. https://doi.org/10.1177/079160350501400202

Cremades, Á., Álvarez, C., Urruzola, M. J., Jaramillo, C., \& Hernández, G. (1995). Coeducación y tiempo libre. Madrid: Popular.

Devís-Devís, J., \& Pereiró-Velert, C. (1993). La actividad física y la promoción de la salud en niños y jóvenes: La escuela y la educación física. Revista de Psicología del Deporte/Journal of Sport Psychology, 2, 71-86. http://www.rpd-online.com/article/view/293/28910

Durán, E. (2001). Las creencias de los profesores: Un campo para deliberar en los procesos de formación. Revista de Acción Educativa, 1.

Eaton, W., \& Von Bargen, D. (1981). Asynchronous Development of Gender Understanding in Preschool Children. Child Development, 52, 1020-1027. https://doi.org/10.2307/1129107

Emmerich, W., \& Sheperd, K. (1982). Development of Sex Differentiated Preferences during Late Childhood and Adolescence. Development Psychology, 18, 406-417. https://doi.org/10.1037/0012-1649.18.3.406

Espada-Calpe, J. M. (2004). Poder, masculinidad y virilidad. Extracto de ponencia ofrecida en el Curso Técnico Especialista en Igual de Oportunidades en el Empleo. Albacete, España: IMUMEL.

Fernández, M. L. (2011). Los estereotipos de género en las clases de educación física en el nivel medio (tesis de licenciatura). Argentina: Universidad Abierta Interamericana.

Flick, U. (2004). Introducción a la investigación cualitativa. Madrid, España: Ediciones Morata S.L.

Garret, C., \& Kehr, C. (1985). Educational Equity and Sex Role Development. In S. Klein, (Ed.), Handbook for Achieving Sex Equity through Education (pp. 78-89). Baltimore, MD: Johns Hopkins University Press.

Gil-Madrona, P., \& Contreras-Jordán, O. (2005). Enfoques actuales de la educación física y el deporte. Retos e interrogantes: El Manifiesto de Antigua, Guatemala. Revista Iberoamericana de Educación, No. 39, 225-256.

https://rieoei.org/historico/documentos/rie39a09.pdf

Goetz, J., \& Le Compte, M. D. (1988). Etnografía y diseño cualitativo en investigación educativa. Madrid, España: Ediciones Morata S.A.

Gunderson, E., Ramírez, G., Levine, S., \& Beilock, S. (2012). The Role of Parents and Teachers in the Development of Gender-Related Math Attitudes. Sex Roles, 66, 153-166. https://doi.org/10.1007/s11199-011-9996-2

Le Compte, M. D., \& Schensul, J. (1999). Analyzing y interpreting ethnographic data. Walnut Creek, CA: Altamira Press.

Leaper, C., \& Brown Christia, S. (2014). Sexism in Schools. En L. S. Liben, \& R. S. Bigler (Eds.), Advances in Child Development and Behavior (pp. 2-422). Cambridge, MA: Academic Press. https://doi.org/10.1016/bs.acdb.2014.04.001

Martin, C. L., Fabes, R., \& Hanish, L. (2014). Chapter Five. Gendered-Peer Relationships 
in Educational Contexts. The Role of Gender in Educational Contexts. Advances in Child Development Behavior, 47, 151-187. https://doi.org/10.1016/bs.acdb.2014.04.002

Martínez-Andrés, M., Bartolomé-Gutiérrez, R., Rodríguez-Martín, B., Pardo-Guijarro, M., \& Martínez-Vizcaíno, V. (2017). "Football Is a Boys' Game”: Children’s Perceptions about Barriers for Physical Activity during Recess Time. International Journal of Qualitative Studies on Health and Well-being, 12, Article ID: 1379338. https://doi.org/10.1080/17482631.2017.1379338

Maxwell, J. (2002). Understanding Validity in Qualitative Research. En: A. M. Huberman, \& M. B. Miles (Eds.), The Qualitative Research's Companion (Chapter 2). Thousand Oaks, CA: Sage Publications.

McConaghy, M. (1979). Gender Permanence and the Genital Basis of Gender: Stages in the Development of Constancy of Gender Identity. Child Development, 50, 1223-1226. https://doi.org/10.2307/1129354

Ministerio de Educación Pública (2005). Programa de Educación física. San José, Costa Rica: MEP (Ministerio de Educación Pública).

Ministry of Education (2015). The Ontario Curriculum Grades 9 to 12: Health and Physical Education. Canada.

Moreno-Doña, A. (2011). Percepciones del profesorado universitario de Educación física en relación a la función de transformación social de la Educación física escolar. el caso de Chile (Doctorado). Granada, Spain: Universidad de Granada.

Pelegrín Muñoz, Antonia, León Campos, J. M., Ortega Toro, E., \& Garcés de Los Fayos, E. (2012). Programa para el desarrollo de actitudes de igualdad de género en clases de educación física en escolares. Educación XX1: Revista de la Facultad de Educación, 15, 271-291.

Perry, D., \& Bussey, K. (1979). The Social Learning Theory of Sex Differences: Imitation Is Alive and Well. Journal of Personality and Social Psychology, 37, 1699-1712. https://doi.org/10.1037/0022-3514.37.10.1699

Piedra, J. (2015). Masculinidades en educación física: El nuestro es un deporte de "machos" V Ciclo de Conferencias Xénero, Actividade Física e Deporte, 2013-2014/2014-2015/. Lecture, Coruña.

Piedra, J., Anderson, E., Colás-Bravo, P., Fernández-García E., Gard, M. et al. (2013). Géneros, masculinidades y diversidad. Barcelona: Octaedro.

Piedra, J., García Pérez, R., Latorre Romero, Á., \& Quiñones Delgado, C. (2013). Género y Educación Física. Análisis de Buenas Prácticas Coeducativas. Revista De Curriculum Y Formación Del Profesorado, 17, 1699-1712. http://www.ugr.es/ recfpro/rev171ART13.pdf

Pochet, R. M.. (2000). Discurso y análisis social. Métodos cualitativos y técnicas de análisis. San José, Costa Rica: Universidad de Costa Rica.

Portela Guarín, H. (2001). Paradigmas del cuerpo en la educación física. Revista Digital-Buenos Aires, 2, 1.

Pozo, J. I. (2000). Concepciones de aprendizaje y cambio educativo. Ensayos y Experiencias, 6, 4-13.

Pruzzo De Di Pego, V. (2005). Aportes para la profesionalización docente: Una mirada desde la investigación acción. Revista Praxis Educativa, 9, 50-60.

Pruzzo De Di Pego, V., \& Nosei, C. (2008). Alumnos que no aprenden Historia: ¿problemas de la Didáctica? Revista Praxis Educativa, 12, 41-56.

Puig Barata, N., \& Soler Prat, S. (2004). Mujer y deporte en España: Estado de la cuestión y propuesta interpretativa. Apunts, 76, 71-78. 
http://www.revista-apunts.com/es/hemeroteca?article $=277$

Quintana-Cabanas, J. M. (2001). Las creencias y la educación. Pedagogía cosmovisional. Barcelona España: Herder.

Robnett, R., \& Susskind, J. (2010). Who Cares about Being Gentle? The Impact of Social Identity and the Gender of One's Friends on Children's Display of Same-Gender Favoritism. Sex Roles, 63, 820-832. https://doi.org/10.1007/s11199-010-9843-x

Rodríguez Gómez, G., Gil Flores, J., \& García Jiménez, E. (1996). Metodología de la investigación cualitativa. Archidona: Aljibe.

Rosales Paneque, F., Vicente Hernández, V., \& Fleitas Céspedes, R. (2005). Creencias de resultados, expectativas y motivos del profesorado de la educación física: Su influencia en el desarrollo del proceso docente educativo. Revista Digital Buenos Aires, 10, 1.

Santander, P. (2011). Por qué y cómo hacer Análisis de Discurso. Cinta De Moebio, No. 41, 207-224. http://www.redalyc.org/articulo.oa?id=10119954006 https://doi.org/10.4067/S0717-554X2011000200006

Saraví, J. (1995). Hacia una Educación Física no sexista. Educación Física Y Ciencia, 1, 32-39.

Scharagrodsky, P. (2004). Juntos pero no revueltos: La educación física mixta en clave de género. Cuadernos De Pesquisa, 34, 59-76. https://doi.org/10.1590/S0100-15742004000100004

Schensul, S., Le Compte, M. D., \& Schensul, J. (1999). Essential Ethnographic Methods. Walnut Creek, CA: Altamira Press.

Slaby, R., \& Frey, K. (1985). Development of Gender Constancy and Selective Attention to Same Sex Models. Child Development, 46, 849-856.

https://doi.org/10.1111/j.1467-8624.1975.tb04029.x

Subirats-Martóri, M. (1988). Panorámica sobre la situación educativa de las mujeres: Análisis y políticas. En M. Subirats, Rosa y Azul. La transmisión de los géneros en la escuela mixta (pp. 201-214). Instituto de la Mujer.

Toro, S. (2007). Una aproximación epistemológica a la didáctica de la motricidad desde el discurso y práctica docente. Estudios pedagógicos, 33, 29-43.

https://doi.org/10.4067/S0718-07052007000100002

Traynor, M. (2015). Focus Group Research. Nursing Standard, 29, 44-48. https://doi.org/10.7748/ns.29.37.44.e8822

Vázquez, B. (2001a). Los fundamentos de la educación física. En B. Vázquez (Coord.), Bases educativas de la actividad física y el deporte (pp. 47-68). Madrid: Editorial Síntesis.

Vázquez, Benilde. (2001b). Los valores corporales y la Educación Física: hacia una reconceptualización de la Educación Física. Agora Para La Educación Física y el Deporte, 1, 7-17.

Vidiella, J., Herraiz, F., Hernández, F., \& Sancho, J. (2010). Masculinidad hegemónica, deporte y actividad física. Movimiento, 16, 93-115.

https://doi.org/10.22456/1982-8918.15031

http://www.redalyc.org/articulo.oa?id=115316963006

Woods, P. (1987). La escuela por dentro. Barcelona: Paidós.

World Health Organization (1995). Physical Status: The Use and Interpretation of Anthropometry. Report of a WHO Expert Committee. Technical Report Series No. 854. Geneva: World Health Organization. 